\title{
IMPLEMENTASI TITIK KOORDINAT TENGAH KABUPATEN ATAU KOTA DALAM PERHITUNGAN JADWAL WAKTU SALAT
}

\author{
Moelki Fahmi Ardliansyah
}

\author{
Universitas Islam “45” (Unisma), Bekasi \\ e-mail: moelkifahmi@gmail.com
}

\begin{abstract}
Study literature of Islamic Astronomy in case prayer times, is less from getting specific attention. Furthermore, the schedule of prayer times is very complex. Such as its still being distributed in form converting one to another area. It should be computed based on each district or city. Appearing new case that is coordinates point data (latitude and longitude) where used as center point computations. This thesis is researched the effect and importance implementation of center coordinate point from district or city in the determining of prayer times schedule. The research used mathemathic analytic descriptive and comparative analysis methods. With purpose to know in detail the comparation result from prayer times computations using center coordinate point and otherwise. The result of research shows the effect prayer times schedule can be applied for one district or city area. Meanwhile, computed prayer times schedule that use another center point coordinate not exactly can be applied in one district or city area. Though coordinate different value more than $0,5^{\circ}$ and its position located in the south and east center coordinate point. Center coordinate point must be applied because at the base this coordinate point have been considered geographical aspect. Where in width side for the north, south, east and west have been considered and have the equilibrium distance.
\end{abstract}

Kajian studi Astronomi Islam dalam persoalan waktu salat kurang mendapat perhatian khusus. Padahal persoalan jadwal waktu salat sangat komplek, seperti masih beredarnya jadwal waktu salat yang dikonversi dari satu daerah ke daerah lain. Sudah seharusnya jadwal waktu salat disusun berdasarkan kabupaten atau kota masing-masing. Persoalan baru yang muncul adalah data titik koordinat (lintang dan bujur) mana yang akan digunakan sebagai acuan perhitungannya. Dalam tulisan ini meneliti dampak dan perlunya implementasi titik koordinat tengah kabupaten atau kota dalam perhitungan jadwal waktu salat. Penelitian ini menggunakan metode deskriptif analitis matematis dan analisis komparatif, yang bertujuan untuk mengetahui secara detail hasil perbandingan perhitungan jadwal waktu salat dengan menggunakan titik koordinat tengah dan selain titik koordinat tengah. Penelitian ini menemukan bahwa, dampaknya jadwal waktu salat dapat diberlakukan untuk satu wilayah kabupaten atau kota. Sedangkan jadwal waktu salat yang diperhitungkan menggunakan selain titik koordinat tengah belum tentu dapat diberlakukan untuk satu wilayah kabupaten atau kota, apalagi selisih koordinatnya diatas $0,5^{\circ}$ dan posisinya berada di sebelah selatan dan timur dari titik koordinat tengah. Titik koordinat tengah perlu diimplementasikan, karena pada dasarnya titik koordinat ini telah mempertimbangkan aspek geografis. Dimana dalam segi luas untuk bagian utara, selatan dan timur, barat nya telah dipertimbangkan dan jaraknya pun seimbang.

Keywords: jadwal waktu salat; titik koordinat tengah; wilayah kabupaten atau kota 


\section{Pendahuluan}

Jadwal waktu salat saat ini lebih dipilih oleh masyarakat sebagai acuan dalam memulai salat dibandingkan dengan melihat fenomena pergerakan secara langsung. Hal ini terjadi karena perjalanan Matahari itu relatif tetap, maka terbit, tergelincir dan terbenamnya dapat diperhitungkan dengan mudah. Demikian pula kapan Matahari itu akan membuat bayang-bayang suatu benda sama panjang dengan bendanya, juga dapat diperhitungkan untuk setiap hari sepanjang tahun. Oleh karena itu, mudah jika orang akan melakukan salat hanya dengan melihat jadwal yang sudah berdasarkan perhitungan falak. ${ }^{1}$

Pergerakan Matahari yang sudah dianggap relatif tetap pada setiap hari sepanjang tahun yang dijadikan dasar dalam perhitungan jadwal waktu salat terkesan tidak ada masalah. Padahal, dalam kajian studi Astronomi Islam persoalan waktu salat kurang mendapat perhatian khusus. Menurut Azhari, masih sangat kompleks persoalan jadwal waktu salat, mulai dari permasalahan waktu salat Subuh dan Isya yang tidak sesuai hasil observasi, penginformasian jadwal waktu salat yang tidak ada sumber, sampai masalah jadwal waktu salat sepanjang masa beserta konversi ke daerah lain. ${ }^{2}$ Meskipun secara umum sistem perhitungan jadwal waktu salat di Indonesia mengalami kemajuan dari tahun ke tahun, yakni dari yang menghitung dengan manual menggunakan kalkulator, bantuan komputer sampai memprogramkannya menjadi sebuah software. ${ }^{3}$

Sebetulnya dalam sejarah pemikiran Astronomi Islam penggunaan konversi atau koreksi daerah dalam jadwal waktu salat merupakan isu penting yang harus dikaji. Menurut Wahid, sebaiknya jadwal waktu salat disusun berdasarkan kota masing-masing dan menghindari penggunaan konversi

\footnotetext{
1Penentuan awal waktu salat dengan sistem hisab merupakan bagian dari ilmu falak yang perhitungannya ditetapkan berdasarkan garis edar Matahari atau penentuan posisi Matahari terhadap Bumi. Baca: A. Mukri Agrafi, Aplikasi Hisab Rukyat, (t.tp, 2002), h. 53.

2Susiknan Azhari, Catatan \& Koleksi Astronomi Islam dan Seni (Yogyakarta: Museum Astronomi Islam dan Pintu Publishing, 2015), h. 148-165.

3Dahlia Haliah Ma'u, "Jadwal Salat Sepanjang Masa di Indonesia (Studi Akurasi dan Batas Perbedaan Lintang dalam Konversi Jadwal Salat)", Disertasi, Universitas Islam Negeri Walisongo Semarang, 2013, h. 4.
} 
daerah dengan cara mengurangi dan menambah.4 Apabila merujuk pada jadwal salat yang mengunakan sistem konversi maka pasti ada sedikit ketidaksesuaian. Karena pada dasarnya konversi tersebut hanya mempertimbangkan koreksi garis bujur tanpa mempertimbangkan garis lintang. Oleh karena itu sistem koordinat geografis ${ }^{5}$ suatu kota sangat urgen keberadaannya dalam memperhitungkan jadwal waktu salat.

Akan lebih baik jika jadwal salat berbasis markas kabupaten atau kota, namun ketika jadwal salat sudah diperhitungkan berdasarkan masing-masing kabupaten atau kota, ${ }^{6}$ persoalan baru yang muncul adalah data titik koordinat (lintang dan bujur) mana yang akan digunakan sebagai acuan perhitungannya. Selama ini masih banyak yang menggunakan data dari Atlas Der Gehele Aarde oleh PR Bos - JF Nier Meyer JB, Wolters Groningen, Jakarta, 1951. Padahal kita tahu keakurasian data tersebut. Dahulu penentuan data lintang dan bujur tempat suatu kota biasanya diukur pada titik di pusat kota. Setelah kota itu mengalami perkembangan maka luas kota akan bertambah dan tidak mustahil daerah yang tadinya pusat kota akibatnya menjadi pinggiran kota. Akibat dari perkembangan ini maka ujung timur dan ujung barat suatu kota akan mempunyai jarak yang cukup jauh dari titik penentuan lintang dan bujur kota sebelumnya.

Akibat dari koordinat yang tidak sesuai dengan yang benar-benar pusat kota maka hasil perhitungan jadwal waktu salatnya belum mencakup seluruh

\footnotetext{
4Basit Wahid, “Penentuan Waktu-waktu Salat", Suara Muhammadiyah, No. 8/81/1996. Pendapat tersebut diperjelas oleh Dimsiki Hadi yang menyatakan : "Konversi waktu yang berlaku selama ini sebenarnya hanyalah berlaku tatkala Matahari berada diatas ekuator. Dalam keadaan ini lama waktu siang dan malam untuk semua tempat sama yaitu 12 jam. Tetapi dalam realitasnya Matahari tidak selamanya berada di ekuator. Hal ini yang menyebabkan konversi waktu salat tidak konstan sepanjang tahun". Baca HM. Dimsiki Hadi, Sains untuk Kesempurnaan Ibadah (Yogyakarta: Prima Pustaka, 2009).

${ }^{5}$ Sistem koordinat geografis menggunakan permukaan bola (spheres) tiga dimensi (three dimensional spherical surface) untuk mendefinisikan suatu lokasi di permukaan Bumi. Suatu titik ditentukan oleh nilai bujur dan lintang, dimana garis tersebut merupakan sudut yang diukur dari pusat Bumi ke titik permukaan Bumi yang diukur. Sudutnya sering dinyatakan dalam derajat (degree) atau radian (grad). Indarto, Sistem Informasi Geografis (Yogyakarta: Graha Ilmu, 2013), h. 125. Baca juga Hasanuddin Abidin, Geodesi Satelit (Jakarta: PT. Pradnya Paramita, 2001), h. 15.

${ }_{6}^{6}$ Menurut Izzuddin, "Perlu dibangun kesepakatan pemberlakuan jadwal salat dalam wilāyatul hukmi kabupaten atau kota. Tidak perlu membuat jadwal salat dalam tiap kecamatan apalagi tiap desa". Ahmad Izzuddin, "Panduan Jadwal Imsakiyah (Merumuskan Jadwal Imsakiyah Standart di Jawa Tengah", (Makalah Lokakarya Imsakiyah 1436 H, Semarang: Kanwil Kemenag Provinsi Jawa Tegah, 19 Mei 2015), h. 3.
} 
daerah. Hanya berlaku pada titik pusat kota dan daerah sebelah timurnya saja dan tidak berlaku untuk daerah sebelah baratnya, meskipun ditambahkan waktu ihtiyāt $t^{7}$ untuk mengantisipasi sebelah baratnya. Mungkin antisipasi waktu ihtiyāt bisa digunakan untuk kota yang tidak terlalu luas, apabila daerahnya luas maka waktu ihtiyāt tidak bisa mencakup jadwal waktu salat untuk kota tertentu dan memerlukan waktu ihtịyāt yang sangat besar.8 Sehingga diperlukan titik koordinat tengah kota yang dijadikan acuan. ${ }^{9}$

Uraian di atas menggambarkan pentingnya mengkaji dan menganalisis titik koordinat tengah kabupaten atau kota dalam perhitungan jadwal waktu salat, karena pada satu sisi tidak jadi permasalahan apabila besar wilayah kota tersebut tidak begitu luas. Namun wilayah kota yang sangat luas, perlu adanya solusi dalam mengambil acuan titik koordinat dalam perhitungan waktu salat. Apakah dengan begitu luasnya wilayah kota dapat tercakup dalam satu jadwal salat. Bagaimana dampaknya serta perbandingan hasil perhitungan yang menggunakan titik koordinat tengah dan yang tidak menggunakan titik koordinat tengah. Serta mengapa perlu mengimplementasikan titik koordinat tengah dalam perhitungan jadwal waktu salat.

\section{Perkembangan Metode Penyusunan Jadwal Waktu Salat di Indonesia}

Suatu kenyataan bahwa terdapat banyak jadwal waktu salat yang dipergunakan oleh masyarakat saling berbeda. Hal ini disebabkan beberapa hal:

${ }^{7}$ Ihtiyat adalah suatu langkah pengaman dengan cara menambahkan atau mengurangkan waktu beberapa menit dari hasil perhitungan agar jadwal waktu salat tidak mendahului awal waktu atau melampaui akhir waktu. Depag, Badan Hisab dan Rukyah. Almanak Hisab Rukyah, Oakarta: Proyek Pembinaan Badan Peradilan Agama Islam Depag RI, 1981), h. 38.

${ }^{8}$ Nilai ihțiyat berkisar antara 1-4 menit, tetapi karena semakin presisinya perhitungan hisab saat ini maka dianjurkan untuk menggunakan ihtiyat tidak lebih dari 2 menit kecuali untuk waktu Zuhur. Ahmad Mushonnif, Ilmu Falak (Metode Hisab Awal Waktu Salat, Arah Kiblat, Hisab Urfi dan Hisab Hakiki Bulan), (Yogyakarta: Teras, Cet I, 2011), h. 66.

${ }^{9}$ Lembaga yang berkompeten mengeluarkan data titik koordinat adalah Badan Informasi Geospasial (BIG) yang dulu bernama Bakosurtanal. Kementerian Agama mulai mensosialisasikan data koordinat itik tengah tanggal 1 Oktober 2013. Hal ini disepakati untuk standarisasi hisab rukyat (hisab waktu salat dan arah kiblat), saat Temu Kerja Hisab Rukyat Kemenag RI yang dilaksanakan di Sempur Park Hotel Bogor pada tanggal 3-5 April 2014. Baca Izzuddin, "Panduan Jadwal Imsakiyah", h. 3 . 
Pertama, perbedaan cara sistem penyusunan. Pada awalnya semua hari dan tempat ditandai dengan waktu yang sama, yakni Zuhur selalu jam 12, Asar jam 3 sore, Magrib jam 6 sore, Isya jam setegah 8 malam dan Subuh setengah 5 pagi. Namun kemudian diketahui bahwa Matahari itu tidaklah tetap, maka perlu diperhitungkan deklinasinya.

Kedua, perbedaan ihtịyatt. Para penyusun jadwal berbeda-beda dalam menetapkan berapa menit waktu yang dijadikan sebagai langkah pengamanan ini, ada yang 2 menit, 4 menit dan sebagainya. Hal ini yang menyebabkan jadwal akan berbeda-beda meskipun sistem penyusunannya sama.

Ketiga, adanya konversi waktu salat suatu kota ke kota lain. Adanya penambahan dan pengurangan pada jadwal salat untuk kota tertentu. Hal ini mengakibatkan ketidaksesuaian dengan fenomena alam sebenarnya. Ada beberapa jenis jadwal waktu salat sistem konversi ini, antara lain:10 a) Jadwal yang berlaku di kota terentu dan mencantumkan konversi dengan daerah sekitar; b) Jadwal yang berlaku di kota tertentu dan mencantumkan konversi dengan kota-kota besar di Indonesia; c) Jadwal yang berlaku di kota tertentu dan mencantumkan konversi dengan kota-kota besar di pulau Jawa dan luar pulau Jawa; d) Jadwal yang berlaku pada selisih lintang membatasi keberlakuan lintang dalam konversinya.

Mengacu pada jenis jadwal salat yang dipaparkan di atas, maka sesungguhnya jadwal waktu salat yang beredar di masyarakat rata-rata menggunakan konversi atau koreksi waktu salat dari satu kota/daerah ke kota/daerah yang lain. Konversi atau koreksi itu dilakukan dengan cara melakukan penambahan beberapa menit waktu bagi kota/daerah yang berada di bagian barat dan melakukan pengurangan beberapa menit bagi daerah/kota yang berada di bagian timur dari kota yang dijadikan acuan pengambilan waktu salatnya. ${ }^{11}$ Dengan begitu perlu adanya pedoman yang dapat dijadikan acuan oleh umat Islam untuk mengatasi hal tersebut. Sudah barang tentu pedoman tersebut harus memuat kaidah yang dibenarkan oleh agama dan ilmu pengetahuan.

10Ma’u, “Jadwal Salat Sepanjang Masa”, h. 82-92.

${ }^{11}$ Penambahan dan pengurangan beberapa menit tersebut, didasarkan pada selisih bujur tempat dibagi 15 derajat. Angka 15 diperoleh dari teori bahwa dalam sekali rotasi bumi sama dengan $360^{\circ}$ yang ditempuh selama sekitar 24 jam dan setiap jam menempuh jarak $15^{\circ}$. Lihat George 0 Abell, etal, Exploration of The Universe, (New York : Saunders College Publishing, 1987), h. 104. 
Perhitungan jadwal waktu salat mengalami perubahan dari waktu ke waktu, diiringi dengan kajian astronomis yang ada. Hal ini menunjukkan supaya dalam hal ibadah juga memertimbangkan aspek ilmiah. Ada beberapa hal yang mengalami transformasi tersebut:

Pertama, data koordinat yang digunakan acuan dalam perhitungan. Koordinat dalam buku-buku falak relatif sama dan terkesan turun temurun. Padahal daerah kabupaten atau kota terus mengalami perkembangan. Ada yang sudah menggunakan data yang mutakhir hanya saja acuannya alun-alun atau masjid yang mewakili daerah tersebut.

Kedua, pengambilan data deklinasi dan equation of time. Pada awalnya data deklinasi dan equation of time mengambil dari tabel-tabel dalam kitab klasik. Kemudian karena dirasa datanya statis sedangkan Matahari geraknya dinamis, akhirnya dicoba untuk menghitung pendekatan dengan mempertimbangkan bujur Matahari pada tanggal tertentu. Namun kini data tersebut dapat diperoleh melalui buku ephemeris yang di dalamnya terdapat perhitungan yang akurat.

Ketiga, perumusan ketinggian Matahari. Rumusan tinggi Matahari masingmasing pakar berbeda pendapat, namun Kementerian Agama RI merumuskan ketinggian Matahari adalah -1,-18,-20 untuk Magrib, Isya dan Subuh. Ketinggian tersebut sudah mempertimbangkan koreksi diameter, refraksi dan kerendahan ufuk. Dengan rincian - $\left(16^{\prime}+34^{\prime}+10^{\prime}\right)$. Harga semidiameter dan refraksi, apabila ingin lebih teliti maka kerendahan ufuk diperhitungkan kembali.12

Keempat, algoritma perhitungan. Kini telah disepakati algoritma baku untuk hisab arah kiblat dan waktu salat. Kementerian Agama RI sudah melakukan standardisasi Hisab Rukyat, bahkan sudah didesain berbasis IT yakni dalam SIHAT Indonesia (Sistem Informasi Hisab Rukyat Indonesia. Standardisasi ini dihasilkan subdit Pembinaan Syariah dan Hisab Rukyat Direktorat Urusan Agama Islam dan Pembinaan Syariah Direktorat Jendral Bimbingan Masyarakat Islam Kementerian Agama RI saat mengadakan Temu kerja hisab rukyat Kemenag RI yang dilaksanakan di Sempur Park Hotel Bogor pada tanggal 3-5 142

${ }^{12}$ Dirjen Bimbingan Masyarakat Islam, Almanak Hisab Rukyat, (Jakarta: Kemenag RI, 2010), h. 
April 2014 dengan tema Standardisasi Hisab Rukyat: Sebuah Upaya Penyatuan Umat. ${ }^{13}$

\section{Membangun Jadwal Waktu Salat Berbasis Geografis Astronomis}

Jadwal waktu salat merupakan hasil perhitungan waktu salat yang disusun dalam jangka waktu tertentu guna dijadikan acuan dalam memulai salat. Manfaatnya adalah mempermudah dan memberikan informasi lebih awal sehingga seseorang dapat mengatur waktu di tengah kesibukan aktifitas sehari-hari. Tentu jadwal waktu salat yang dihitung dengan kaedah formulasi astronomi harus dapat juga dipertanggungjawabkan secara syar'i, artinya dalam hal jadwal waktu salat jangan sampai berbeda antara fenomena alam yang terjadi dengan hasil perhitungan yang ada.

Di dalam jadwal waktu salat biasanya tidak hanya memuat 5 waktu salat saja, terkadang ditambah dengan waktu Imsak,14 waktu Terbit dan Duha. Ini untuk memberikan informasi supaya umat Muslim dapat berhati-hati dalam memulai puasa yakni dengan waktu Imsak, dan mengakhiri waktu salat Subuh, serta mengetahui kapan yang tepat melaksanakan salat Duha. Terkadang juga ada jadwal imsakiyah yang diterbitkan setiap bulan Ramadhan, jadwal ini harusnya tidak berbeda dengan jadwal salat yang berlaku selama ini. Hanya digunakan untuk evaluasi data jadwal salat yang ada, sehingga tidak perlu membuat jadwal salat baru.

Menurut Izzuddin ${ }^{15}$ (ahli Ilmu Falak UIN Walisongo Semarang), jadwal waktu salat akan lebih baik jika dalam membuat dan menyusun perhitungan dengan berbasis markas kabupaten atau kota masing-masing dan data astronomis yang update. Dengan demikian tidak zamannya lagi, jika membuat jadwal salat dengan melakukan penyesuaian jadwal salat dengan tambah atau

\footnotetext{
${ }^{13}$ simbi.kemenag.go.id/sihat/waktu-solat

${ }_{14}$ Waktu imsak yang biasanya dengan mengurangi 8 menit atau 10 menit, 12 menit atau 15 menit sebelum awal waktu salat sesuai ijtihad dalam memperkirakan waktu nabi Muhammad saw dalam membaca 50 ayat al-Quran. Ahmad Izzuddin menyatakan bahwa adanya waktu imsak sebelum waktu salat shubuh hanya merupakan tradisi masyarakat muslim Asia Tenggara dalam rangka ihțiyāt malam memulai puasa. Baca Ahmad Izzuddin, "Jadwal Imsakiyah yang Berbasis Unity of Sciences", (Makalah Lokakarya Imsakiyah 1438 H, Semarang:LP2M UIN Walisongo, tanggal 12 April 2017), h. 3.

15M. Solahudin, Ahli Falak dari Pesantren (Kediri: Nous Pustaka Utama, 2012), h. 38.
} 
kurang dengan kabupaten atau kota yang lain. ${ }^{16}$ Penyusunan jadwal waktu salat setidaknya memperhatikan dan mempertimbangkan hal sebagai berikut: 1) Algoritma atau rumus hisab awal salat dengan data yang diperlukan dalam menghitung ketinggian Matahari, merujuk pada aturan baku standardisasi hisab rukyah Kemenag RI; 2) Data titik koordinat (lintang dan bujur) yang dipakai data lintang bujur yang terbaru dengan menggunakan markaz data di titik tengah kabupaten atau kota terkait; ${ }^{17}$ 3) Pemberlakukan jadwal salat dalam wilāyat al-hukmi kabupaten atau kota. Tidak perlu membuat jadwal salat dalam tiap kecamatan apalagi tiap desa; ${ }^{18}$ 4) Waktu ihtitiyāt yang disepakati. Waktu ihtiyyat dimaksud sebagai langkah pengamanan dengan cara menambah atau mengurangi waktu agar jadwal waktu salat tidak mendahului awal waktu salat atau melampaui akhir waktu salat. Langkah yang ditempuh adalah dengan pembulatan angka dalam satuan detik dibulatkan menjadi satu menit. Kementerian Agama RI sejak 1979, menggunakan ihtiyāt 2 menit sebagaimana Saadoedin Djambek, yang sudah dianggap cukup memberikan pengamanan;19 5) Jadwal disusun perhari supaya hitungan dapat akurat.

Aspek astronomis yang harus diperhatikan dalam penyusunan jadwal waktu salat adalah Matahari pada posisi tertentu. Perjalanan Matahari setiap harinya baik terbit maupun terbenam itu tidak sebenarnya. Melainkan disebabkan oleh perputaran Bumi pada sumbunya (rotasi) sehari semalam, sehingga perjalanan seperti itu disebut perjalanan semu Matahari. Selain itu Matahari melakukakan perjalanan semu tahunan ke arah timur dalam waktu 365,2425 hari dan posisi Matahari tidak tepat pada equator langit melainkan miring $23^{\circ}$ 27'. Sehingga posisi Matahari (deklinasi terhadap equator) pada setiap harinya berubah, dan menyebabkan waktu salat berbeda setiap harinya. ${ }^{20}$

\footnotetext{
16Jayusman, "Jadwal Waktu Salat Abadi," Khatulistiwa : Journal of Islamic Studies, Vol. 3, No. 1, Maret 2013, h. 67.

${ }^{17}$ Lembaga yang berkompeten mengeluarkan data titik koordinat adalah Badan Informasi Geospasial (BIG) yang dulu bernama Bakosurtanal. Mulai disosialisasikan tanggal 1 Oktober 2013.

${ }^{18}$ Sebagai gambaran selisih 1 menit pada garis khatulistiwa bumi apabila berjarak 27,83 km dari markaz diambil dari keliling bumi dibagi waktu rotasi (40075 km: 1440 menit). Sehingga pemberlakuan jadwal salat dalam satu wilayah kabupaten atau kota dengan markaz hisab dititik tengah kabupaten atau kota tersebut diasumsikan masih bisa menjangkau.

192Depag RI, Pedoman Penentuan Jadwal Salat Sepanjang Masa, (Jakarta: Depag RI, 1985), h. 37-39.

${ }^{20}$ A. Frangky Soleiman, “Penentuan Awal Waktu Salat," Jurnal Ilmiah al-Syir'ah, Vol. 9, No. 2 (2011), h. 13.
} 
Selain hal di atas, yang menyebabkan waktu salat berbeda pada setiap harinya adalah equation of time, yakni selisih waktu pertengahan dan waktu hakiki. Waktu hakiki berdasarkan perputaran bumi tidak tentu 24 jam, namun jam yang kita gunakan menggunakan waktu pertengahan / rata-rata, sehingga perlu ada penyesuaian. Hal ini disebakan peredaran Bumi mengelilingi Matahari berbentuk elips dan Matahari berada pada salah satu titik apinya. Nilai equation of time pun setiap hari dalam setahun tidak statis, sehingga perlu adanya data yang akurat dalam perhitungan waktu salat. ${ }^{21}$

Selanjutnya aspek astronomis posisi Matahari pada waktu salat adalah sudut waktu Matahari, yakni busur sepanjang lingkaran harian Matahari dihitung dari titik kulminasi atas sampai Matahari berada. Nilai sudut waktu $0^{\circ}$ sampai $180^{\circ}$, bernilai positif apabila di sebelah barat meridian dan negatif apabila di sebalah timurnya, dan titik $0^{\circ}$ berada pada titik kulminasi atas pada meridian langit.22

Dengan pertimbangan di atas maka jadwal waktu salat dihitung berdasarkan perhari untuk lebih akurat dan kehatian-hatian. Apabila Konsep astronomis tersebut digabungkan dengan kajian fikih maka melahirkan jadwal waktu salat yang berbasis saintifik dan syar'i.

Jadwal waktu salat yang baik adalah jadwal yang dapat mencakup daerah dalam satu kota. Meskipun secara astronomis dapat diperhitungkan masingmasing kecamatan atau desa. Namun, yang dititiktekankan disini adalah kemaslahatan. Kemaslahatan dibangun untuk saling menghormati hak sesama manusia. Apabila jadwal dibangun berdasarkan acuan kota maka dalam satu kota adzan akan serentak. Sehingga tidak mengganggu kenyamanan aktifitas orang lain.

Akurasi waktu salat belum berarti maslahat, maksudnya ketika seorang ahli falak dapat menghitung waktu salat ditempat ia berdiri, maka ia tidak boleh menfatwakan hasil perhitungannya. Artinya hasil perhitungannya hanya berlaku untuk dirinya, bukan untuk masyarakat secara umum, karena apabila diterapakan maka akan terjadi kebingungan dan ketidaknyamanan di

\footnotetext{
21Muhyiddin Khazin, Ilmu Falak dalam Teori dan Praktik, cet ke IV (Yogyakarta: Buana Pustaka, 2008), h. 67.

22Ibid., h. 81.
} 
masyarakat. Jadi jadwal waktu salat mempertimbangkan aspek maslahat dan harus dicarikan solusi dan kajian supaya dapat akurat. Sehingga terjadi sinkronisasi antara syar'i dan saintifik.

\section{Metode Penentuan Titik Koordinat Tengah Kabupaten atau Kota}

Pada dasarnya mencari titik tengah suatu daerah adalah mempertimbangkan segala aspek luas daerah yang dicakupnya. Dalam kartografi titik tengah atau yang disebut juga centroid merupakan titik tengah dari suatu wilayah geografis. Misalnya, centroid dari wilayah kabupaten X merupakan titik yang letaknya tepat di tengah-tengah wilayah kabupaten tersebut.

Pusat geometri (centroid) dikenal juga dengan sebutan centre of gravity atau center of mass. Dalam matematika maupun fisika, pusat geometri dari sebuah area dua dimensi merupakan posisi rata-rata aritmatika dari semua titik pembatas area tersebut. ${ }^{23}$ Untuk menghitung luas area bentuk poligon dalam bidang datar dua dimensi (xy) digunakan persamaan sebagai berikut. ${ }^{24}$

$$
A=\frac{1}{2} \sum_{i=0}^{n-1}\left(x_{i} y_{i+1}-x_{i+1} y_{i}\right) \quad(2-1)
$$

\footnotetext{
Keterangan:

$A$ : luas area poligon

xi: posisi titik ke-i pada poligon berdasarkan sumbu x

yi: posisi titik ke-i pada poligon berdasarkan sumbu y

$\mathrm{n}$ : banyaknya titik pada poligon
}

\footnotetext{
23Francis E. Greulich, “Accurate Polygon Centroid Computation," Journal of Computing in Civil Enginering 9(1) : 8 Januari 1995.

${ }^{24}$ Paul Bourke, Calculating the Area and Centroid of a Polygon, University of Western Australia, diakses pada 23 April 2017, http://local.wasp.uwa.edu.au/ pbourke/geometry/polyarea/
} 


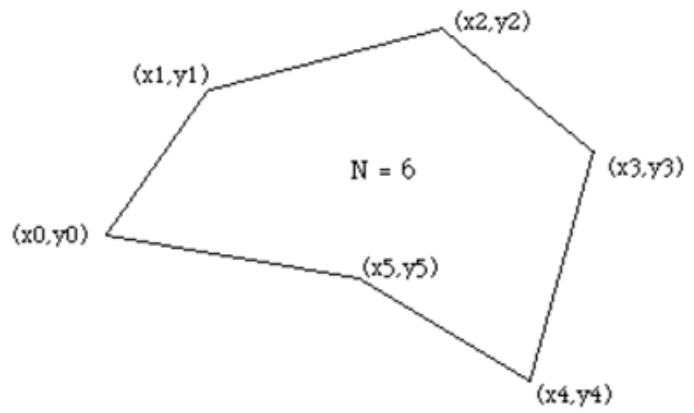

Gambar 1.

Area Poligon

Poligon adalah rangkaian titik-titik secara berurutan, sebagai kerangka dasar pemetaan. Untuk kepentingan kerangka dasar, titik-titik poligon tersebut harus diketahui atau ditentukan posisinya atau koordinatnya. Jumlah titik sampel pada satu poligon bergantung pada luas poligon tersebut. Semakin besar poligon semakin banyak titik simpul yang ada pada satu poligon. Poligon dapat dihitung luasnya apabila titik sudut diketahui koordinatnya.

Dalam persamaan (2-1) titik simpul diberikan nomor secara berurutan sepanjang garis poligon dan titik simpul ( $\mathrm{xn}, \mathrm{yn})$ sama dengan titik simpul ( $\mathrm{x} 0$, y0) sebagai poligon tertutup. Jika titik simpul diberi nomor urut searah jarum jam maka nilai variabel A akan negatif, tetapi posisi koordinat pusat geometri akan tetap benar. Titik tengah atau pusat geometri dari sebuah poligon tertutup yang terdiri dari sejumlah n titik simpul dapat ditentukan menggunakan persamaan (2-2) dan (2-3) dengan menggunakan rumus: 25

$$
\begin{aligned}
& C_{x}=\frac{1}{6 A} \sum_{i=0}^{n-1}\left(x_{i}+x_{i+1}\right)\left(x_{i} y_{i+1}-x_{i+1} y_{i}\right) \\
& C_{y}=\frac{1}{6 A} \sum_{i=0}^{n-1}\left(y_{i}+y_{i+1}\right)\left(x_{i} y_{i+1}-x_{i+1} y_{i}\right)
\end{aligned}
$$

25Bourke, Calculating the Area, h. 3. 
Moelki Fahmi Ardliyansah
Keterangan:
Cx: Pusat geometri poligon berdasarkan sumbu x
Cy: Pusat geometri poligon berdasarkan sumbu y

Hasil perhitungan pusat geometri dari setiap poligon berdasarkan koordinat Kartesius xy merupakan titik koordinat berdasarkan bujur dan lintang geografisnya.

Ada beberapa cara lain yang dapat digunakan dalam menentukan titik centroid antara lain dengan menggunakan software ArcGIS atau menghitung Momen Inersia Poligon cembung tidak teratur. Software ArcGIS26 digunakan untuk mempermudah dalam pemetaan. Sedangkan dalam menghitung Momen Inersia Poligon cembung tidak teratur ada beberapa tahapan.

Saat inersia dibutuhkan untuk menghitung pergerakan rotasi suatu bentuk daerah. Hal itu dapat dianggap sebagai rotasi yang setara dengan massa. Untuk menghitung momen inersia harus mengintegrasikan area (volume dalam 3D) dari poligon yang berhubungan dengan sumbu rotasi (sumbu tidak melalui pusat massa). Cara yang dilakukan sebagai berikut :27

Pertama, poligon di triangulasi ${ }^{28}$ dengan mengitari sekitar centroid (pusat massa), sehingga centroid adalah bagian dari setiap segitiga.

\footnotetext{
${ }^{26}$ Software ini digunakan dalam pemetaan wilayah secara geografis dan dimanfaatkan dalam segala bidang, yakni dalam sebuah sistem informasi geografis. Contoh pemanfaatan sistem informasi geografis, baca Erna Kharistiani dan Eko Ariwibowo, "Sistem Informasi Geografis Pemetaan Potensi SMA/SMK Berbasis Web (Studi Kasus : Kabupaten Kebumen)," Jurnal Sarjana Teknik Informatika, Vol. 1 No. 1, Juni 2013. Baca Rossi Hamzah, dkk, "Metode Penentuan Titik Koordinat Zona Potensi Penagkapan Ikan Pelagis Berdasarkan Hasil Deteksi Termal Front Suhu Permukaan Laut," Jurnal Penginderaan Jauh Vol. 13 No. 2 Desember 2016, h. 97-108. Baca juga Muhammad Arizar Hidayat, dkk, "Pemodelan Pertumbuhan Tata Ruang Kota Semarang Berdasarkan Aspek Ekonomi Menggunkan Konsep Analisis Spasial Citra Satelit Resolusi Tinggi," Jurnal Geodesi, Undip, Vol. 5 No. 4 Agustus 2016.

${ }^{27}$ Michael, Calculating the Moment of Inertia of a non-regular convex Polygon, diakses pada tanggal 20 April 2017, http://lab.polygonal.de/2006/08/17/calculating-the-moment-of-inertia-of-a-convexpolygon/

${ }^{28}$ Clark Kimberling, "Trilinear Distance Inequalities forthe Symmedian Point, the Centroid, and Other Triangel Centers," Forum Geom : Forum Geometricorum, Vol. 10 (2010), h. 135-139.
} 
Implementasi Titik Koordinat Tengah Kabupaten atau Kota ....

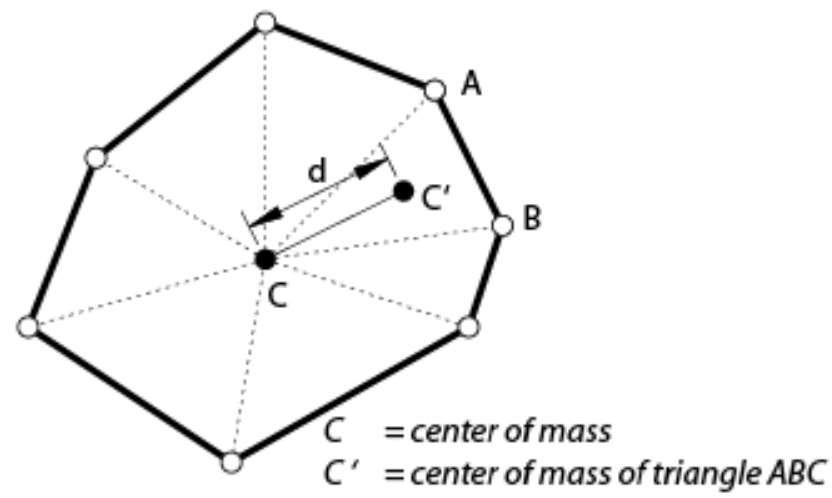

Gambar 2.

Titik Tengah Poligon

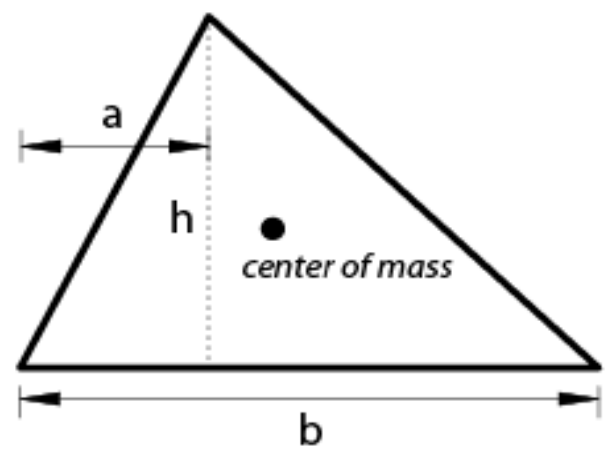

Gambar 3.

Segitiga Poligon

Sekarang centroid segitiga dan momen inersia segitiga tentang sumbu melalui pusat massa segitiga harus dihitung.

$$
I_{\text {triangle }}=\frac{b^{3} h-b^{2} h a+b h a^{2}+b h^{3}}{36}
$$

Poligon asli berputar sekitar sumbu melalui pusat massa poligon asli, jadi kita harus menggunakan sumbu paralel. Aturan tersebut menyatakan bahwa 
momen inersia tentang sumbu yang sejajar dengan satu melalui centroid dapat dihitung dengan menambahkan massa (dalam hal ini kita menggunakan area segitiga sebagai massa) dikalikan dengan jarak terpendek kuadrat ke sumbu paralel. Langkah terakhir adalah meringkas semua momen inersia segitiga.

$$
I_{\text {total }}=\sum_{k=1}^{n}\left(I_{\text {triangle }}+M d^{2}\right)_{k}
$$

\section{Pengaruh Perbedaan Koordinat Geografis pada Jadwal Waktu Salat}

Pergerakan Matahari yang dilihat selama ini bukan merupakan pergerakan yang sebenarnya, melainkan oleh pergerakan Bumi berotasi atau berevolusi yang kemudian dinamakan gerak semu Matahari yang mengakibatkan banyak hal. Semua itu (posisi Matahari) akan berbeda ketika berbeda pula tempatnya dan waktunya.

Perbedaan waktu pada jadwal waktu salat dapat dipengaruhi oleh perbedaan tempat. Acuan untuk memahami perbedaan waktu tersebut adalah mengetahui konsep koordinat geografis, dimana titik refrensinya adalah lintang dan bujur tempat. Oleh karenanya dengan perbedaan koordinat lintang dan bujur maka posisi Matahari pun akan berbeda dan waktunya pun akan berbeda.

Tempat yang memiliki garis lintang yang sama maka panjang siang dan malamnya sama pula. ${ }^{29}$ Dimana hal ini berkaitan dengan peredaran Matahari yang menurut garis edarnya selalu berpindah-pindah dari utara ke selatan. Ketika Matahari berada di utara maka tempat yang kedudukannya di lintang utara akan mengalami masa siang yang berbeda dengan tempat yang berada di lintang selatan, demikian sebaliknya. Oleh sebab itu, maka tidak tepat apabila jadwal waktu salat mencantumkan konversi untuk daerah lain yang notabenenya terpaut selisih garis lintangnya.

Sedangkan garis bujur yang titik 0 nya berada di kota Greenwich, akan mempengaruhi perbedaan waktu pada setiap garis bujur. ${ }^{30}$ Garis bujur juga

\footnotetext{
${ }^{29}$ Chatief Kunjaya, Menuju Oliempiade Astronomi, Jilid I (Bandung : ITB, 2006), h. 24.

30 Ibid.
} 
dijadikan acuan dalam pembagian zona waktu, dimana zona waktu tersebut setiap 15 derajat bujur memiliki selisih 1 jam. Jika waktu standar di sebelah barat bujur 0 maka waktunya dikurangi, sebaliknya disebelah timur bujur 0 derajat waktunya ditambah. Sebagaimana diketahui Indonesia berada pada bujur 105 - 135 derajat maka Indonesia terbagi dalam 3 zona waktu yakni WIB, WITA dan WIT.

Zona waktu ini sangat berperan kaitannya dengan penyusunan jadwal waktu salat. Dimana waktu yang kita gunakan selama ini adalah berbasis pada waktu daerah sedangkan yang dimaksudkan dalam awal waktu salat adalah fenomena yang benar-benar terjadi pada daerah tertentu dengan koordinat tertentu. Maka perlu adanya koreksi waktu daerah dengan waktu setempat.

Selain itu, garis bujur itu bernilai 0 - 180 derajat ke timur dan 0 - 180 derajat ke barat, berarti jumlahnya ada 360 derajat. Apabila dalam sehari semalam Bumi berotasi 360 derajat selama 24 jam maka dapat diartikan setiap 1 jam akan menempuh 15 derajat garis bujur. Hal ini mengindikasikan bahwa untuk setiap 1 derajat bujur perbedaan waktunya adalah 4 menit.

Dengan begitu, hal ini akan mempengaruhi jadwal waktu salat apabila terdapat selisih bujur antara satu tempat dengan yang lain. Namun konsep ini terkadang disalahartikan, dimana selama ini yang beredar di masyarakat terdapat konversi jadwal waktu salat dari satu kota ke kota lain dengan acuan perbedaan garis bujur saja. Apabila selisih bujurnya 1 derajat maka selisih waktunya 4 menit. Praktik konversi jadwal waktu salat yang semacam ini tidak tepat, karena tidak mempertimbangkan selisih garis lintang.

Dahlia dalam penelitian disertasinya menyatakan bahwa dalam sistem konversi jadwal waktu salat tidak boleh selisih garis lintangnya melebihi 1 derajat. ${ }^{31}$ Karena apabila melebihi ketentuan itu maka waktunya sudah tidak tercakup dalam waktu ihtiyāț. Oleh sebab itu, ia menegaskan dalam penelitiannya untuk tidak mengkonversi jadwal waktu salat melebihi selisih lintang 1 derajat.

Namun, hemat penulis dalam penyusunan jadwal salat yang ideal adalah jadwal salat yang berbasis kota atau kabupaten tanpa adanya konversi dengan daerah lain. Sedangkan data yang dijadikan acuan dalam perhitungannya

31Ma’u, “Jadwal Salat Sepanjang..." , h. 203. 
adalah data koordinat titik tengah dari kota atau kabupaten tersebut, dimana koordinat tersebut telah mempertimbangkan seluruh bagian daerah, baik bagian barat, timurnya atau utara selatanya. Oleh karena itu, dengan menggunakan koordinat titik tengah dan di tambah dengan ihțiyāt 2 menit, telah mencakup satu wilayah kabupaten atau kota.

\section{Dampak Implementasi Koordinat Tengah dalam Penyusunan Jadwal Waktu Salat}

Penulis mencoba untuk mencari selisih titik koordinat tengah kota dan koordinat yang selama ini digunakan dalam acuan atau markaz perhitungan untuk waktu salat, baik garis lintang ataupun garis bujur. Data yang di olah adalah koordinat kota dan kabupaten seluruh Indonesia yang berjumlah 511. Data koordinat yang dijadikan acuan adalah koordinat titik tengah yang dibandingkan dengan koordinat pusat keramaian yang ditandai dengan kantor walikota atau alun-alun dan masjid yang representatif di kabupaten atau kota tersebut.

Dari 511 data, penulis menyaring selisih koordinat yang di atas $0,5^{\circ}$ baik selisih lintang atau bujur. Alasan yang digunakan adalah dari teori-teori yang telah dipaparkan sebelumnya bahwa perbedaan lintang akan berpengaruh pada waktu salat apabila telah lebih dari $1^{\circ}$ dan perbedaan bujur $1^{\circ}$ sama dengan 4 menit, atau 1 menit setara dengan jarak kurang lebih $27,5 \mathrm{~km}$. Oleh karena itu untuk lebih hati-hati penulis mengambil acuan selisih $0,5^{\circ}$ untuk menyaring datanya. Berikut hasil penyaringan dari 511 data:

Tabel 1.

Selisih Koordinat $>0,5^{\circ}$

\begin{tabular}{|c|c|c|c|c|}
\hline No. & Provinsi & $\begin{array}{c}\text { Kabupaten/ } \\
\text { Kota }\end{array}$ & $\begin{array}{c}\text { Selisih } \\
\text { Koordinat }\end{array}$ & Keterangan \\
\hline 1. & Riau & Pelalawan & $0,55935^{\circ}$ & Sebelah Barat titik Center \\
\hline 2. & Kepulauan Riau & Bintan & $0,81951^{\circ}$ & Sebelah Barat titik Center \\
\hline 3. & Palembang & $\begin{array}{l}\text { Ogan } \\
\text { Komering Ilir }\end{array}$ & $0,58388^{\circ}$ & Sebelah Barat titik Center \\
\hline 4. & Jawa Timur & Sumenep & $0,80008^{\circ}$ & Sebelah Barat titik Center \\
\hline 5. & Kalimantan & Ketapang & $0,54394^{\circ}$ & Sebelah Barat titik Center \\
\hline 6. & Barat & Sintang & $0,52981^{\circ}$ & Sebelah Barat titik Center \\
\hline 7. & $\begin{array}{l}\text { Kalimantan } \\
\text { Tengah }\end{array}$ & Seruyan & $1,20740^{\circ}$ & $\begin{array}{l}\text { Sebelah Selatan titik } \\
\text { Center }\end{array}$ \\
\hline
\end{tabular}

228 || Volume 27, Nomor 2, Oktober 2017 
Implementasi Titik Koordinat Tengah Kabupaten atau Kota ....

\begin{tabular}{|c|c|c|c|c|}
\hline \multicolumn{2}{|l|}{8.} & Kapuas & $1,13504^{\circ}$ & $\begin{array}{l}\text { Sebelah Selatan titik } \\
\text { Center }\end{array}$ \\
\hline \multicolumn{2}{|l|}{9.} & Murung Raya & $0,58742^{\circ}$ & $\begin{array}{l}\text { Sebelah Selatan titik } \\
\text { Center }\end{array}$ \\
\hline 10. & $\begin{array}{l}\text { Kalimantan } \\
\text { Timur }\end{array}$ & $\begin{array}{l}\text { Kutai } \\
\text { Kartanegara }\end{array}$ & $-0,57285^{\circ}$ & Sebelah timur titik Center \\
\hline 11. & $\begin{array}{l}\text { Kalimantan } \\
\text { Utara }\end{array}$ & Malinau & $\begin{array}{l}-1,01179^{\circ} \\
-0,93190^{\circ}\end{array}$ & $\begin{array}{l}\text { Sebelah Utara titik Center } \\
\text { Sebelah timur titik Center }\end{array}$ \\
\hline 12. & & Nunukan & $-0,95891^{\circ}$ & Sebelah timur titik Center \\
\hline 13. & $\begin{array}{l}\text { Sulawesi } \\
\text { Selatan }\end{array}$ & $\begin{array}{l}\text { Kepulauan } \\
\text { Selayar }\end{array}$ & $-0,69642^{\circ}$ & Sebelah Utara titik Center \\
\hline \multirow{2}{*}{$\begin{array}{l}14 . \\
15 .\end{array}$} & Sulawesi & Sigi & $-0,56165^{\circ}$ & Sebelah Utara titik Center \\
\hline & Tengah & $\begin{array}{l}\text { Parigi } \\
\text { Moutong }\end{array}$ & $0,80419^{\circ}$ & $\begin{array}{l}\text { Sebelah Selatan titik } \\
\text { Center }\end{array}$ \\
\hline 16. & Maluku & $\begin{array}{l}\text { Maluku Barat } \\
\text { Daya }\end{array}$ & $0,55048^{\circ}$ & $\begin{array}{l}\text { Sebelah Selatan titik } \\
\text { Center }\end{array}$ \\
\hline \multirow{3}{*}{$\begin{array}{l}17 . \\
18 . \\
19 .\end{array}$} & Papua Barat & Tambarauw & $0,58094^{\circ}$ & Sebelah Barat titik Center \\
\hline & & Fakfak & $0,56989^{\circ}$ & Sebelah Barat titik Center \\
\hline & Papua & Puncak & $0,59367^{\circ}$ & $\begin{array}{l}\text { Sebelah Selatan titik } \\
\text { Center }\end{array}$ \\
\hline \multicolumn{2}{|l|}{20.} & Asmat & $0,57179^{\circ}$ & Sebelah Barat titik Center \\
\hline \multicolumn{2}{|l|}{21.} & Sarmi & $-0,59707^{\circ}$ & Sebelah Utara titik Center \\
\hline \multirow[t]{2}{*}{22.} & & Marauke & $0,59255^{\circ}$ & $\begin{array}{l}\text { Sebelah Selatan titik } \\
\text { Center }\end{array}$ \\
\hline & & & $-0,89616^{\circ}$ & Sebelah timur titik Center \\
\hline
\end{tabular}

Melihat 22 data di atas posisinya berbeda-beda terhadap koordinat tengah. Ada selisih koordinat $0,5^{\circ}$ yang posisinya berada pada sebelah barat koordinat tengah, maka tentu sesuai teori yang ada maka sebelah timur akan mengalami waktu salat terlebih dahulu. Artinya apabila koordinat tengah yang berada di sebalah timur saja sudah dapat mencakup seluruh daerah, maka apabila ada koordinat alun-alun yag berada di sebalah baratnya akan sangat terjaga jadwal waktu salatnya.

Untuk posisi sebelah barat atau timur dari koordinat tengah akan sangat mudah untuk dianalisis secara cepat. Secara otomatis data yang berada di sebelah barat koordinat tengah dieliminir atau dapat ditinggalkan untuk tidak dianalisa berikutnya. Sedangkan untuk yang berada pada utara atau selatan koordinat tengah, perlu adanya pembuktian secara perhitungan. Berikut ini hasil perhitungan untuk koordinat yang berada di utara atau selatan koordinat tengah: 
Penulis menampilkan 2 koordinat kota yang posisinya berada di sebalah utara koordinat tengah dan selatannya. Diambil sempel kabupaten Murung Raya yang berada $0^{\circ} 35^{\prime} 14,71^{\prime \prime}$ sebelah selatan koordinat tengah dan Kabupaten Kepulauan selayar $0^{\circ} 41^{\prime} 47,11^{\prime \prime}$ sebelah utaranya. 2 koordinat ini coba dibandingkan dalam menghitung waktu Magrib dalam tahun 2017.

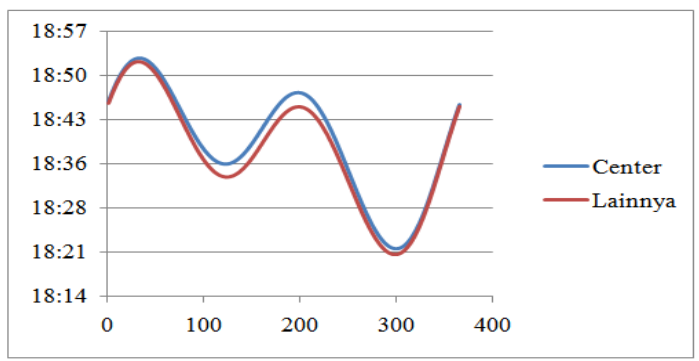

Gambar 4.

\section{Diagram Jadwal Waktu Salat Magrib Kabupaten Murung raya}

Data dari diagram di atas menghasilkan selisih maksimal 0j 02m 25d dan minimal $0 \mathrm{j} 00 \mathrm{~m} 22 \mathrm{~d}$. Hasil menggunakan koordinat tengah lebih lambat, sehingga untuk perhitungan yang tidak menggunakan koordinat tengah belum mencakup seluruh daerah.

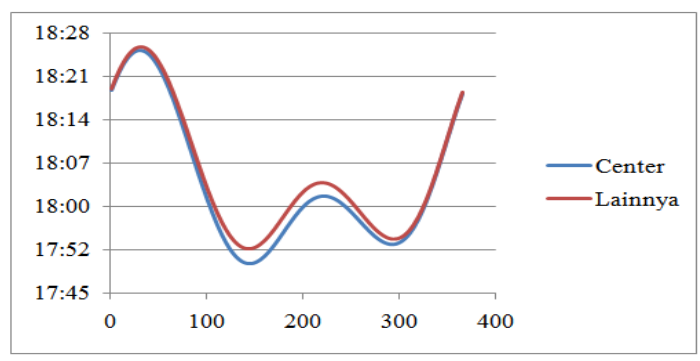

\section{Gambar 5.}

Diagram Jadwal Waktu Salat Magrib Kabupaten Kepulauan Selayar

Data dari diagram di atas menghasilkan selisih maksimal 0j 02m 33d dan minimal $0 \mathrm{j} 00 \mathrm{~m}$ 06d. Hasil menggunakan koordinat tengah lebih cepat, sehingga apabila menggunakan data selain koordinat tengah seperti halnya koordinat yang berada di barat koordinat tengah jadwal waktu salat akan mencakup seluruh daerah. 
Jadi, dalam penyusunan jadwal salat dari analisa di atas dapat ditarik sebuah kesimpulan bahwa: 1) Koordinat tengah, ideal untuk di implementasikan sebagai acuan perhitungan jadwal waktu salat, karena mempertimbangkan seluruh daerah; 2) Koordinat lain dapat di jadikan sebagai acuan perhitungan jadwal waktu salat apabila selisih dengan koordinat tengah di bawah $0,5^{\circ}$ baik lintang atau bujurnya; 3) Koordinat yang berada sebelah utara atau barat koordinat tengah tidak menjadi masalah, karena waktunya lebih lambat dari hasil perhitungan yang menggunakan koordinat tengah.

\section{Urgensitas Implimentasi Titik Koordinat Tengah dalam Perhitungan Jadwal Waktu Salat}

Ketampakan alam Indonesia terdiri dari perairan dan daratan yang berbanding antara 4:1. Masing-masing pulau, provinsi dan kota, luas dan bentuknya pun akan berbeda-beda. Setidaknya ada beberapa pengklasifikasian untuk bentuk kota-kota di Indonesia, yakni ada yang melintang dan membujur. Hal ini akan berpengaruh terhadap posisi koordinat tengahnya. Tak jarang juga terdapat beberapa koordinat tengah yang berada di tengah laut, karena daerahnya terdapat lautan.

Dari data 511 kota disaring menjadi 22 kota yang selisih koordinatnya terpaut jauh dengan koordinat tengah. Kemudian disaring lagi untuk daerah barat dan selatan koordinat tengah yang waktunya lebih lambat, menjadi 10 kota. Dengan rincian sebagai berikut:

Tabel 2.

Luas dan Jarak Kota atau Kabupaten

\begin{tabular}{clccc}
\hline No. & Kabupaten/Kota & Koordinat Center & Luas Daerah & Jarak \\
\hline 1. & Seruyan & $\begin{array}{l}-2,20694^{\circ} \mathrm{LS} \\
112,1308^{\circ} \mathrm{BT}\end{array}$ & 14292,018 & $143 \mathrm{~km}$ \\
& & $-1,82972^{\circ} \mathrm{LS}$ & 16852,265 & $130 \mathrm{~km}$ \\
2. & Kapuas & $\begin{array}{l}114,3636^{\circ} \mathrm{BT} \\
-0,05333^{\circ} \mathrm{LS}\end{array}$ & 24138,984 & \multirow{2}{*}{$194 \mathrm{~km}$} \\
& & $114,2211^{\circ} \mathrm{BT}$ & & \\
3. & Murung Raya & $-0,03222^{\circ} \mathrm{LS}$ & 26005,290 & $223 \mathrm{~km}$ \\
& & $116,4258^{\circ} \mathrm{BT}$ & & \\
4. & Kutai Kartanegara & $2,574167^{\circ} \mathrm{LU}$ & 38545,350 & $249 \mathrm{~km}$ \\
& & $115,7147^{\circ} \mathrm{BT}$ & &
\end{tabular}


Moelki Fahmi Ardliyansah

\begin{tabular}{lllcc} 
6. & Nunukan & $3,958056^{\circ} \mathrm{LU}$ & 15640,489 & $254 \mathrm{~km}$ \\
7. & & $116,6919^{\circ} \mathrm{BT}$ & & \\
& & $-0,00139^{\circ} \mathrm{LS}$ & 4617,677 & $157 \mathrm{~km}$ \\
8. & Malukigi Moutong & $\begin{array}{l}120,0356^{\circ} \mathrm{BT} \\
-7,59917^{\circ} \mathrm{LS}\end{array}$ & 9112,344 & $310 \mathrm{~km}$ \\
& & $127,6042^{\circ} \mathrm{BT}$ & & \\
9. & Puncak & $-3,40361^{\circ} \mathrm{LS}$ & 12779 & $131 \mathrm{~km}$ \\
& & $137,5506^{\circ} \mathrm{BT}$ & & \\
10. & Merauke & $-7,91611^{\circ} \mathrm{LS}$ & 44862,096 & $372 \mathrm{~km}$ \\
& & $139,5133^{\circ} \mathrm{BT}$ & & \\
\hline
\end{tabular}

Data jarak pada tabel tersebut diperoleh dari google earth melalui menu ruler, ${ }^{32}$ dengan menarik garis dari garis bujur paling timur ke garis bujur paling barat suatu kota. Dari informasi luas dan jarak dapat di manfaatkan dalam mencari keberlakuan jadwal waktu salat suatu kota berdasarkan garis bujur. Apabila telah diketahui Keliling Bumi maka akan dapat menghitung waktu dan jarak yang ditempuh dalam $1^{\circ}$ busur.

Tabel 3.

Keberlakuan Waktu Salat

\begin{tabular}{cllcc}
\hline No. & Kabupaten/Kota & \multicolumn{1}{c}{ Jari-jari } & Keliling & Jarak Permenit \\
\hline 1. & Seruyan & 6373,669 & 40026,64 & 27,79628 \\
2. & Kapuas & 6375,148 & 40035,93 & 27,80273 \\
3. & Murung Raya & 6378,397 & 40056,33 & 27,8169 \\
4. & Kutai Kartanegara & 6378,399 & 40056,35 & 27,81691 \\
5. & Malinau & 6371,964 & 40015,93 & 27,78884 \\
6. & Nunukan & 6363,187 & 39960,81 & 27,75056 \\
7. & Parigi Moutong & 6378,4 & 40056,35 & 27,81691 \\
8. & Maluku Barat Daya & 6322,381 & 39704,56 & 27,57261 \\
9. & Puncak & 6367,149 & 39985,7 & 27,76784 \\
10. & Merauke & 6317,619 & 39674,65 & 27,55184 \\
\hline
\end{tabular}

Tabel di atas menjelaskan bahwa setiap menit pada lintang yang berbeda maka akan berbeda pula jarak yang ditempuh. Pada jadwal waktu salat, hal ini

\footnotetext{
32 Salah satu menu pada software google earth yang digunakan unutuk mengetahui jarak antara 2 titik atau lebih. Satuan jarak yang dihasilkan dalam kondisi asli adalah mil, tetapi daat diubah dalam satuan lainnya, misalnya inci, yard, kilometer, dll. Baca Efisitek.com, Menjelajah Dunia dengan Google Earth \& Maps (Bandung: CV. YramaWidya, 2006), h. 92.
} 
Implementasi Titik Koordinat Tengah Kabupaten atau Kota ....

digunakan untuk mengetahui seberapa jauh jadwal waktu salat dapat diberlakukan.

Jadi, apabila koordinat tengah diimplementasikan untuk keberlakuan sampai sejauh mana. Maka, setengah dari jarak tersebut sudah tercakup, sedangkan ke baratnya tergantung pada ihțiyāt yang digunakan, dengan ketentuan per menitnya sesuai dengan tabel di atas.

Hasil perhitungan jadwal waktu salat 10 kota yang selisih koordinatnya terpaut jauh dengan koordinat tengah contohnya adalah Jadwal Waktu Salat Kabupaten Seruyan Bulan Mei 2017, Koordinat tengah lintang -2 $2^{\circ} 12^{\prime} 24,98$ ' LS, bujur $112^{\circ} 7^{\prime} 50,88^{\prime \prime}$ BT, tinggi tempat 6 meter.

Tabel 4.

Jadwal Waktu Salat Kabupaten Seruyan

Bulan Mei 2017

\begin{tabular}{llllllllll}
\hline \multicolumn{3}{c}{ Zuhur } & \multicolumn{2}{c}{ Asar } & \multicolumn{2}{c}{ Magrib } & \multicolumn{2}{c}{ Isya } & \multicolumn{2}{c}{ Subuh } \\
\hline $11: 39$ & $11: 37$ & $14: 49$ & $14: 49$ & $17: 41$ & $17: 39$ & $18: 47$ & $18: 45$ & $4: 21$ & $4: 19$ \\
$11: 39$ & $11: 37$ & $14: 49$ & $14: 49$ & $17: 40$ & $17: 38$ & $18: 47$ & $18: 45$ & $4: 21$ & $4: 19$ \\
$11: 38$ & $11: 37$ & $14: 49$ & $14: 49$ & $17: 40$ & $17: 38$ & $18: 46$ & $18: 44$ & $4: 20$ & $4: 19$ \\
$11: 38$ & $11: 36$ & $14: 50$ & $14: 49$ & $17: 40$ & $17: 38$ & $18: 46$ & $18: 44$ & $4: 20$ & $4: 19$ \\
$11: 38$ & $11: 36$ & $14: 50$ & $14: 49$ & $17: 39$ & $17: 37$ & $18: 46$ & $18: 44$ & $4: 20$ & $4: 18$ \\
$11: 37$ & $11: 36$ & $14: 50$ & $14: 50$ & $17: 39$ & $17: 37$ & $18: 45$ & $18: 43$ & $4: 19$ & $4: 18$ \\
$11: 37$ & $11: 36$ & $14: 50$ & $14: 50$ & $17: 39$ & $17: 37$ & $18: 45$ & $18: 43$ & $4: 19$ & $4: 18$ \\
$11: 37$ & $11: 35$ & $14: 50$ & $14: 50$ & $17: 38$ & $17: 36$ & $18: 45$ & $18: 43$ & $4: 19$ & $4: 18$ \\
$11: 37$ & $11: 35$ & $14: 50$ & $14: 50$ & $17: 38$ & $17: 36$ & $18: 45$ & $18: 42$ & $4: 19$ & $4: 17$ \\
$11: 36$ & $11: 35$ & $14: 51$ & $14: 50$ & $17: 38$ & $17: 35$ & $18: 44$ & $18: 42$ & $4: 18$ & $4: 17$ \\
$11: 36$ & $11: 34$ & $14: 51$ & $14: 50$ & $17: 37$ & $17: 35$ & $18: 44$ & $18: 42$ & $4: 18$ & $4: 17$ \\
$11: 36$ & $11: 34$ & $14: 51$ & $14: 50$ & $17: 37$ & $17: 35$ & $18: 44$ & $18: 41$ & $4: 18$ & $4: 17$ \\
$11: 36$ & $11: 34$ & $14: 51$ & $14: 50$ & $17: 37$ & $17: 34$ & $18: 44$ & $18: 41$ & $4: 17$ & $4: 17$ \\
$11: 35$ & $11: 34$ & $14: 51$ & $14: 50$ & $17: 37$ & $17: 34$ & $18: 43$ & $18: 41$ & $4: 17$ & $4: 16$ \\
$11: 35$ & $11: 33$ & $14: 51$ & $14: 50$ & $17: 36$ & $17: 34$ & $18: 43$ & $18: 41$ & $4: 17$ & $4: 16$ \\
$11: 35$ & $11: 33$ & $14: 51$ & $14: 50$ & $17: 36$ & $17: 33$ & $18: 43$ & $18: 40$ & $4: 17$ & $4: 16$ \\
$11: 35$ & $11: 33$ & $14: 51$ & $14: 50$ & $17: 36$ & $17: 33$ & $18: 43$ & $18: 40$ & $4: 16$ & $4: 16$ \\
$11: 34$ & $11: 33$ & $14: 51$ & $14: 50$ & $17: 35$ & $17: 33$ & $18: 43$ & $18: 40$ & $4: 16$ & $4: 15$ \\
$11: 34$ & $11: 33$ & $14: 51$ & $14: 50$ & $17: 35$ & $17: 32$ & $18: 42$ & $18: 40$ & $4: 16$ & $4: 15$ \\
$11: 34$ & $11: 32$ & $14: 52$ & $14: 50$ & $17: 35$ & $17: 32$ & $18: 42$ & $18: 40$ & $4: 16$ & $4: 15$ \\
$11: 34$ & $11: 32$ & $14: 52$ & $14: 51$ & $17: 35$ & $17: 32$ & $18: 42$ & $18: 39$ & $4: 15$ & $4: 15$ \\
$11: 34$ & $11: 32$ & $14: 52$ & $14: 51$ & $17: 34$ & $17: 32$ & $18: 42$ & $18: 39$ & $4: 15$ & $4: 14$ \\
$11: 33$ & $11: 32$ & $14: 52$ & $14: 51$ & $17: 34$ & $17: 31$ & $18: 42$ & $18: 39$ & $4: 15$ & $4: 14$ \\
$11: 33$ & $11: 32$ & $14: 52$ & $14: 51$ & $17: 34$ & $17: 31$ & $18: 42$ & $18: 39$ & $4: 15$ & $4: 14$ \\
$11: 33$ & $11: 31$ & $14: 52$ & $14: 51$ & $17: 34$ & $17: 31$ & $18: 41$ & $18: 39$ & $4: 14$ & $4: 14$ \\
$11: 33$ & $11: 31$ & $14: 52$ & $14: 51$ & $17: 33$ & $17: 31$ & $18: 41$ & $18: 38$ & $4: 14$ & $4: 14$ \\
$11: 33$ & $11: 31$ & $14: 52$ & $14: 51$ & $17: 33$ & $17: 30$ & $18: 41$ & $18: 38$ & $4: 14$ & $4: 13$
\end{tabular}


Moelki Fahmi Ardliyansah

\begin{tabular}{llllllllll}
$11: 33$ & $11: 31$ & $14: 52$ & $14: 51$ & $17: 33$ & $17: 30$ & $18: 41$ & $18: 38$ & $4: 14$ & $4: 13$ \\
$11: 32$ & $11: 31$ & $14: 52$ & $14: 51$ & $17: 33$ & $17: 30$ & $18: 41$ & $18: 38$ & $4: 14$ & $4: 13$ \\
$11: 32$ & $11: 31$ & $14: 52$ & $14: 51$ & $17: 33$ & $17: 30$ & $18: 41$ & $18: 38$ & $4: 13$ & $4: 13$ \\
\hline
\end{tabular}

Jadwal waktu salat kolom pertama merupakan hasil perhitungan menggunakan koordinat tengah. Terlihat lebih lambat, karena untuk mencakup daerah baratnya. Selisih menit dalam satu tahun dapat dilihat pada diagram di bawah ini:

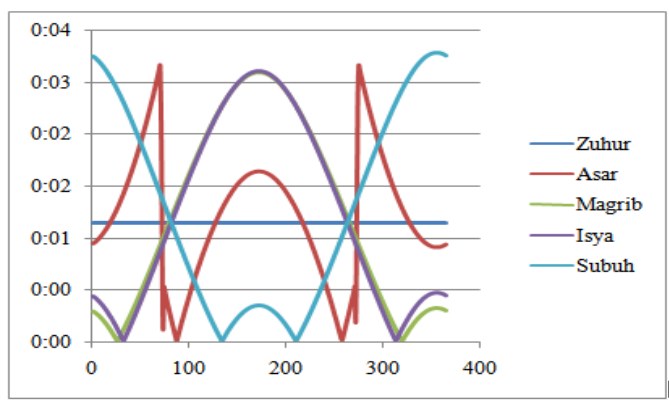

Gambar 6.

Selisih Jadwal Waktu Salat Kabupaten Seruyan

Hasil perhitungan untuk Kabupaten Seruyan dengan koordinat tengah antara 0 menit sampai 4 menit lebih lambat.

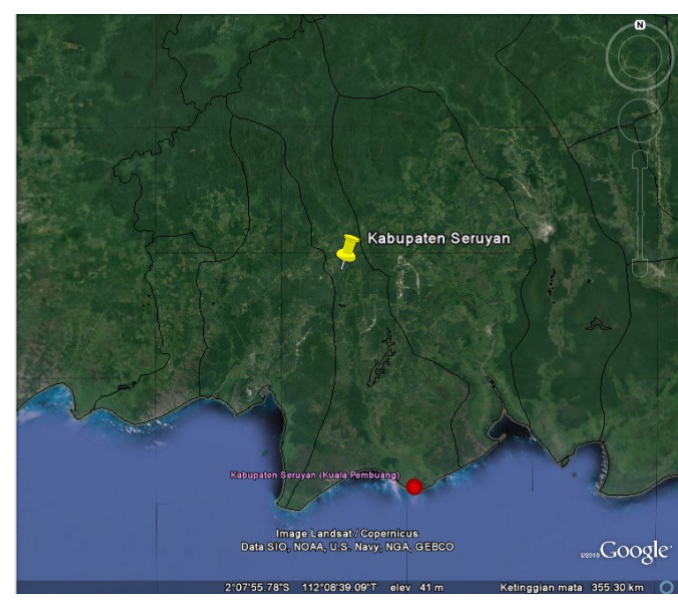

Gambar 7.

Peta Kabupaten Seruyan

234|| Volume 27, Nomor 2, Oktober 2017

AL-AHKAM p-ISSN: 0854-4603; e-ISSN: 2502-3209 
Kabupaten Seruyan merupakan contoh daerah yang koordinat selisihnya pada lintang. Berikut contoh daerah yang selisih koordinat selisihnya pada Bujur, yakni Kabupaten Merauke:

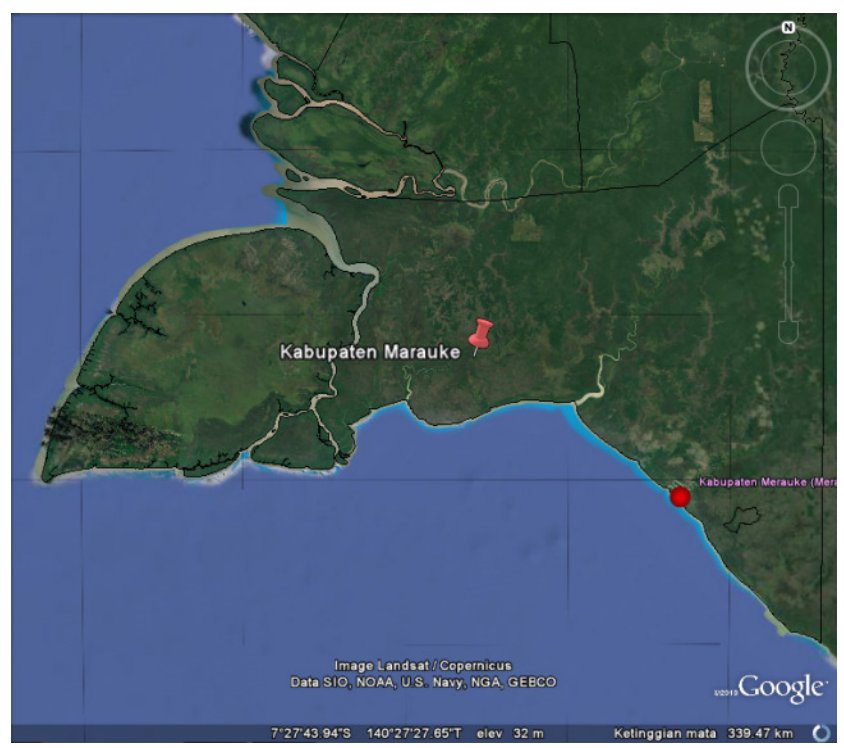

Gambar 8.

Peta Kabupaten Merauke

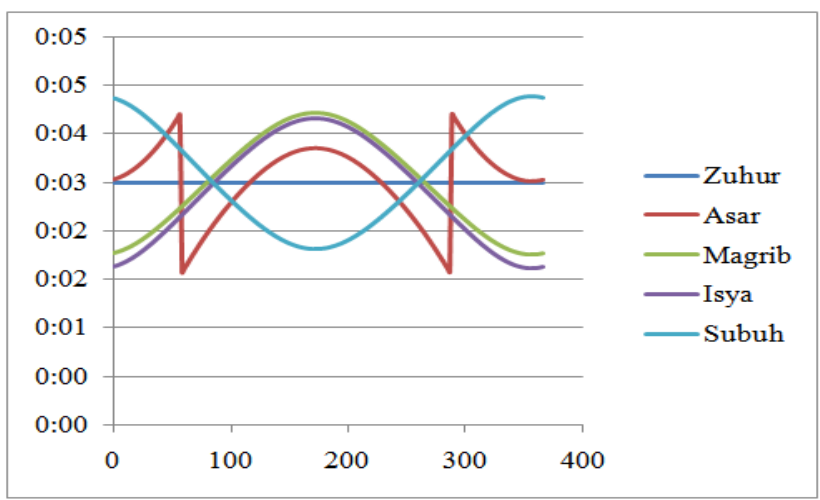

Gambar 9.

Selisih Jadwal Waktu Salat Kabupaten Merauke 
Rekapitulasi hasil dari perhitungan jadwal waktu salat koordinat tengah dengan koordinat lain.

Tabel 5.

Selisih Menit

\begin{tabular}{clc}
\hline No. & \multicolumn{1}{c}{ Kabupaten/Kota } & Selisih \\
\hline 1 & Seruyan & $0-4$ menit \\
2 & Kapuas & $0-2$ menit \\
3 & Murung Raya & $0-2$ menit \\
4 & Kutai Kartanegara & $1-3$ menit \\
5 & Malinau & $1-5$ menit \\
6 & Nunukan & $2-4$ menit \\
7 & Parigi Moutong & $0-2$ menit \\
8 & Maluku Barat Daya & $0-2$ menit \\
9 & Puncak & $0-1$ menit \\
10 & Merauke & $2-5$ menit \\
\hline
\end{tabular}

Jadi perbandingan antara koordinat tengah dengan koordinat lain berkisar antara 0 - 5 menit. Jadwal waktu salat menggunakan koordinat tengah waktunya lebih lambat dari koordinat lain, karena untuk mencakup seluruh wilayah kota.

Koordinat tengah yang posisinya benar-benar berada di tengah yang di implementasikan dalam perhitungan waktu salat mempunyai beberapa fungsi: 1) Sebagai koordinat acuan untuk koordinat lain yang hendak dijadikan sebagai markaz perhitungan; 2) Sebagai koordinat acuan dengan selisih dibawah $0,5^{\circ}$ untuk lintang atau bujur tidak dihiraukan, akan tetapi lebih baik menggunakan koordinat tengah; 3) Sebagai koordinat acuan, apabila koordinat lain yang berada di utara atau barat lebih dipilih karena waktunya lebih lambat dan lebih mencakup; 4) Untuk mencakup seluruh daerah, karena apabila dengan koordinat lain yang selisih jauh akan berbeda waktunya antara 0 - 5 menit; 5) Ihțiyāt 2 menit dengan mengimplementasikan koordinat tengah lebih mencakup.

Dari hasil analisis dijelaskan bahwa selisih terpaut berkisar 0 - 5 menit dengan hasil menggunakan koordinat lain. Hal ini menunjukkan bahwa, apabila koordinat lain menggunakan waktu ihtiyāt belum mencakup seluruh daerah. Dalam tataran aplikatifnya perbedaan koordinat yang digunakan 
dalam perhitungan jadwal waktu salat akan berpengaruh pula terhadap penggunaan ihțiyāt untuk daerah tersebut. Bentuk pengaruhnya antara lain: 1) Apabila terdapat koordinat yang terletak pada bagian barat suatu kota maka ihțiyāt yang digunakan sedikit saja untuk bisa mencakup seluruh daerah. Hal ini yang mendasari apabila terdapat koordinat lain yang berada pada bagian barat koordinat tengah, sebaiknya koordinat lain itu yang digunakan; 2) Jika letak koordinat di bagian timur, sedangkan daerah sebelah baratnya masih panjang, maka ihtiyāt yang digunakan akan banyak. Hal ini dapat disesuaikan dengan perhitungan 1 menit dapat menjangkau berapa jaraknya.

Oleh sebab itu, ihtiyāt sangat penting kehadirannya dalam penyusunan jadwal waktu salat. Apabila disandingkan dengan koordinat tengah, maka tinggal memperhitungkan jarak ke sebelah baratnya untuk menentukan berapa ihtiyāt yang digunakan. Namun setidaknya setengah dari wilayah kota telah tercakup pada jadwal tersebut. Sedangkan apabila dilihat dari sisi perbedaan lintangnya maka apabila telah melebihi 1 derajat ihtiyast ț pun harus diperhitungkan, namun apabila sudah menerapkan koordinat tengah maka daerah yang melintang telah tercakup.

Jadi, apabila mengacu pada konsep jadwal waktu salat yang diberlakukan untuk satu wilayah kota atau kabupaten, maka koordinat tengah dapat mencakup seluruh daerah dengan ihtiyāt yang sedikit. Namun, apabila koordinat lain yang diterapkan sedangkan hasilnya untuk diberlakukan satu wilayah kota akan kesulitan, karena nilai ihtityāt yang digunakan akan banyak.

Jadwal waktu salat yang diidam-idamkan adalah jadwal waktu salat yang keberlakuannya untuk satu wilayah kota atau kabupaten. Sehingga tidak perlu kesulitan dalam merumuskan waktu ihtiyāț. Untuk memenuhi itu tentu faktor geografis harus dipertimbangkan, maka implementasi koordinat tengah sangat ideal untuk perhitungan jadwal waktu salat, dan sebagai koordinat acuan.

\section{Kesimpulan}

Berdasarkan dari uraian di atas dapat ditarik kesimpulan sebagai berikut: Pertama, dampak pengimplementasian koordinat tengah hasilnya akan banyak bersinggungan dengan hasil yang menggunakan koordinat lain yang selisihnya di bawah $0,5^{\circ}$ dengan koordinat tengah. Koordinat tengah lebih penting untuk diimplementasikan apabila terdapat koordinat lain yang berada 
di selatan dan timur koordinat tengah, karena dengan mengimplementasikan koordinat tengah akan lebih mencakup dalam satu wilayah kota.

Kedua, koordinat tengah perlu diimplementasikan dalam jadwal waktu salat, karena pada dasarnya koordinat ini telah mempertimbangkan aspek geografis. Dimana dalam segi luas, untuk bagian utara selatan dan timur barat nya telah dipertimbangkan dan jaraknya pun seimbang. Sehingga apabila diimplementasikan dalam perhitungan jadwal waktu salat setengah bagian dari wilayah suatu kota telah tercakup dan untuk mencakup seluruhnya tidak perlu menambahkan ihtịyāt terlalu banyak, yakni dengan menyesuaikan daerah yang hendak dicakup. [a]

\section{DAFTAR PUSTAKA}

Abbel, George O. et. Al, Exploration of The Universe, New York: Saunders College Publishing, 1987.

Abidin, Hasanuddin, Geodesi Satelit, Jakarta: Pradnya Paramita, 2001.

Agrafi, A. Mukri, Aplikasi Hisab Rukyat, t.tp, 2002.

Azhari, Susiknan, Catatan \& Koleksi Astronomi Islam dan Seni, Yogyakarta: Museum Astronomi Islam dan Pintu Publishing, 2015.

Bourke, Paul, "Calculating the Area and Centroid of a Polygon", University of Western Australia. Diakses pada 23 April 2017, http://local.wasp.uwa. edu.au/ pbourke/geometry/polyarea/.

Depag RI, Pedoman Penentuan Jadwal Salat Sepanjang Masa, Jakarta: Depag RI, 1985.

Depag, Badan Hisab dan Rukyah, Almanak Hisab Rukyat, Jakarta: Proyek Pembinaan Badan Peradilan Agama Islam-Depag RI, 1981.

Dirjen Bimbingan Masyarakat Islam, Almanak Hisab Rukyat, Jakarta: Kemenag RI, 2010.

Efisitek.com, Menjelajah Dunia dengan Google Earth \& Maps, Bandung: CV. Yrama Widya, 2006.

Greulich, Francis E., "Accurate Polygon Centroid Computation", Journal of Computing in Civil Enginering 9 (1): 8 Januari 1995.

Hadi, HM Dimsiki, Sains untuk Kesempurnaan Ibadah, Yogyakarta: Prima Pustaka, 2009. 
Implementasi Titik Koordinat Tengah Kabupaten atau Kota ....

Hamzah, Rossi dkk, "Metode Penentuan Titik Koordinat Zona Potensi Penagkapan Ikan Pelagis Berdasarkan Hasil Deteksi Termal Front Suhu Permukaan Laut", Jurnal Penginderaan Jauh Vol. 13 No. 2 Desember 2016.

Hidayat, Muhammad Arizar, dkk., "Pemodelan Pertumbuhan Tata Ruang Kota Semarang Berdasarkan Aspek Ekonomi Menggunkan Konsep Analisis Spasial Citra Satelit Resolusi Tinggi", Jurnal Geodesi, Vol. 5 No. 4, Undip Agustus 2016.

Indarto, Sitem Informasi Geografis, Jember: Graha Ilmu, 2013.

Izzuddin, Ahmad, "Jadwal Imsakiyah yang Berbasis Unity of Sciences", Makalah Lokakarya Imsakiyah 1438 H, Semarang: LP2M UIN Walisongo, tanggal 12 April 2017.

"Panduan Jadwal Imsakiyah (Merumuskan Jadwal Imsakiyah Standar di Jawa Tengah", Makalah Lokakarya Imsakiyah 1436 H, Semarang: Kanwil Kemenag Provinsi Jawa Tegah, 19 Mei 2015.

Jayusman, "Jadwal Waktu Salat Abadi”, Khatulistiwa: Journal of Islamic Studies, Vol.3 No.1 Maret 2013.

Kharistiani, Erna dan Eko Ariwibowo, "Sistem Informasi Geografis Pemetaan Potensi SMA/SMK Berbasis Web (Studi Kasus Kabupaten Kebumen)”, Jurnal Sarjana Teknik Informatika, Vol.1 No.1, Juni 2013.

Khazin, Muhyiddin, Ilmu Falak dalam Teori dan Praktik, Cet. IV, Yogyakarta: Buana Pustaka, 2008.

Kimberling, Clark, "Trilinear Distance Inequalities forthe Symmedian Point, the Centroid, and Other Triangel Centers", Forum Geom: Forum Geometricorum, Vol. 10, 2010.

Kunjaya, Chatief, Menuju Oliempiade Astronomi, Jil. 1, Bandung : ITB, 2006.

Ma’u, Dahlia Haliah, "Jadwal Salat Sepanjang Masa di Indonesia (Studi Akurasi dan Batas Perbedaan Lintang dalam Konversi Jadwal Salat)", Desertasi, Universitas Islam Negeri Walisongo Semarang, 2013.

Michael, "Calculating the Moment of Inertia of a non-regular convex Polygon", diakses pada tanggal 20 April 2017, http://lab.polygonal.de/ 2006/08/17/calculating-the-moment-of-inertia-of-a-convex-polygon/.

Mushonnif, Ahmad, Ilmu Falak, Metode Hisab Awal Waktu Salat, Arah Kiblat, Hisab Urfi dan Hisab Hakiki Bulan, Cet. Ke I, Yogyakarta: Teras, 2011.

Simbi.kemenag.go.id/sihat/waktu-solat.

Solahudin, M., Ahli Falak dari Pesantren, Kediri: Nous Pustaka Utama, 2012. 


\section{Moelki Fahmi Ardliyansah}

Soleiman, A. Frangky, "Penentuan Awal Waktu Salat", Jurnal Ilmiah al-Syir'ah, Vol. 9 No. 2 (2011).

Wahid, Basit, "Penentuan Waktu-waktu Salat", Suara Muhammadiyah, No. 8/81/1996. 